Please do not destroy or throw away this publication. If you have no further use for it write to the Geological Survey at Washington and ask for a frank to return it

UNITED STATES DEPARTMENT OF THE INTERIOR

Harold L. Ickes, Secretary

GEOLOGICAL SURVEY

W. C. Mendenhall, Director

Professional Paper 185-G

\title{
HALLOYSITE AND ALLOPHANE
}

BY

CLARENCE S. ROSS

AND

PAUL F. KERR

Shorter contributions to general geology, 1934-35

(Pages 135-148)

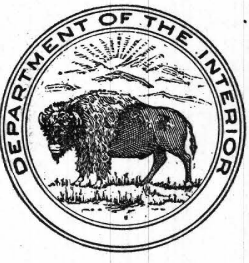

UNITED STATES

GOVERNMENT PRINTING OFFICE

WASHINGTON : 1934

For sale by the Superintendent of Documents, Washington, D. C. - - - - - Price 5 cents 


\section{CONTENTS}

Abstract

Introduction

Halloysite_

Nomenclature

Types _..

Chemical composition

Optical properties

Dehydration

X-ray examination

Mode of occurrence

Associated minerals

Origin

Residual halloysite

Action of acid-bearing solutions

Allophane_.

Previous studies_..

Chemical composition

Optical properties_.

\section{ILLUSTRATIONS}

Plate 28. A, X-ray diffraction patterns of halloysite; $B$, X-ray diffraction patterns of dickite and nacrite

29. A, Photonicrograph of halloysite and alunite; $B$, Photomicrograph of porcelainlike indianaite

Figure 6. Dehydration curves of halloysite and related minerals

7. Diagram of $\mathrm{X}$-ray diffraction patterns of halloysite

8. Dehydration curves of allophane.

II 


\title{
HALLOYSITE AND ALLOPHANE
}

\author{
By Clarence S. Ross and Paul F. Kerr.
}

\begin{abstract}
This paper is a continuation of the study of the kaolin minerals, in the first part of which, published in 1931, the kaolin minerals kaolinite, dickite, and nacrite were described. -In that paper the application of chemical, optical, X-ray, and dehydration methods to the investigation of clay materials were discussed.

The present study shows that halloysite is a fourth mineral of the kaolin group, closely related to but distinct from kaolinite. The chemical, optical, $\mathbf{X}$-ray, and dehydration properties of a representative group of halloysites are recorded, all these being new data determined by the authors on separate portions of single samples whose purity has been carefully tested.
\end{abstract}

Halloysite has been previously described as amorphous, because the microscope commonly reveals no evidence of crystal structure. X-ray diffraction studies, however, show that it has a crystal structure, being made up of crystal grains of submicroscopic size. The X-ray diffraction patterns of kaolinite and halloysite have a number of lines in common, but others are distinct and indicate that these are distinct minerals.

Halloysite appears to be always the result of weathering, or supergene processes, like kaolinite but unlike dickite and nacrite, the other kaolin minerals, which are commonly the result of hydrothermal processes.

Allophane is an amorphous material that is commonly associated with halloysite. It has no crystal structure and no definite chemical composition. The name allophane should be restricted to mutual solutions of silica, alumina, water, and minor amounts of bases but should include all such materials, even though the proportions of these constituents may vary. It is shown that perfectly homogeneous solutions of allophane and other amorphous materials may exist. Thus several occurrences described as "allophane" are found to be such mixtures of normal allophane and evansite, an amorphous hydrous aluminum phosphate.

\section{INTRODUCTION}

A study of the clay minerals has been in progress in the laboratories of the United States Geological Survey and Columbia University for several years. In an earlier paper ${ }^{1}$ the minerals kaolinite, dickite, and nacrite were described. These studies have been continued, and the present paper sets forth the results. Halloysite, like those earlier described, is a mineral of the kaolin group. Allophane is related in mode of occurrence, although, being amorphous, it is quite different mineralogically.

\footnotetext{
${ }^{1}$ Ross, C. S., and Kerr, P. F., The kaolin minerals : U.S. Geol. Survey
} Prof. Paper 165, pp. 151-176, 1931.

\section{HALLOYSITE}

A white or light-colored, approximately isotropic clay mineral known as "halloysite" locally forms small nearly pure masses or is abundantly associated with kaolinite in many kaolin deposits. The association, the chemical composition, the optical data, and the $\mathrm{X}$-ray properties indicate its close relation to the minerals kaolinite, dickite, and nacrite of the kaolin group, but the present study shows that halloysite is a distinct mineral. Not all nearly isotropic clay materials are halloysite, for some prove to be very fine grained kaolinite, and others are clay material of a quite unrelated group. On the other hand, most isotropic clay materials with an index of refraction near that of quartz are the definite clay mineral halloysite.

The original halloysite was found in the Carboniferous limestone of Angleur, Liege, Belgium, in a district of old zinc and iron mines. It was first described in 1826 by Berthier, ${ }^{2}$ and was named "halloysite" in honor of Omalius d'Halloy, who had observed the mineral several years previously. The mineral occurred in pockets containing alteration products and in solution cavities in the limestone. All the deposits are now exhausted, and it is impossible to obtain material from the old mine openings. Several specimens of halloysite from these deposits are, however, still on reserve in the collections of the University of Liege. Through the kindness of Prof. $\mathrm{H}$. Buttgenbach, of the University of Liege, we have been able to procure a suite of specimens of this material, which are probably as nearly representative of type halloysite as it is possible to obtain at the present time.

These specimens have been reexamined and compared with halloysite from other localities. Halloysite has also been compared with the related kaolin minerals-kaolinite, anauxite, nacrite, and dickite-and with other clay minerals. The method of study employed in this work is described in the paper on the kaolin group, already cited. All determinationsoptical properties, X-ray diffraction data, and chemical analyses - have been made on different fractions of the same sample. The chemical and optical studies have been carried on in the laboratories of the United

${ }^{2}$ Berthier, P., Analyse de l'halloysite: Annales chimie et phys., vol. 32 , pp. $332-335,1826$. 
States Geological Survey, and the X-ray studies have been conducted in the mineralogical laboratory of Columbia University. Both these organizations have cooperated in the preparation of this report.

\section{NOMENCLATURE}

Dana lists under halloysite ${ }^{3} 16$ mineral names that he considers to be synonymous with it. Most of these names were proposed before 1850 , the original materials were poorly described, and analyses were made on material of doubtful purity. Obviously most of such materials are not available for restudy, and under such circumstances a detailed consideration of these names, most of which have fallen into complete disuse, would serve no useful purpose. However, a few of these may be briefly mentioned.

The only name that has been consistently applied to the clay mineral here considered is "halloysite", which was proposed 108 years ago. Fortunately, therefore, there is no question of the name that should be retained.

Smectite has been considered to be at least in part halloysite, ${ }^{4}$ but recent studies by Kerr ${ }^{5}$ have shown that the clay material of representative samples is montmorillonite, the typical clay mineral of normal bentonites.

The name "indianaite" was proposed by $\mathrm{Cox}^{6}$ in 1874 for a white porcelainlike clay in the Carboniferous rocks of Lawrence County, Ind. The studies of indianaite given in the present paper (p. 143) show that it is a rock composed of impure halloysite. Cox seems to have recognized that "indianaite" was not the name of a mineral but was to be used as a rock rame, for he says, " "This large bed of white clay to which I have given the name of 'indianaite' (Indiana stone)."

Collyrite (collyrium) was discussed by Dioscorides ${ }^{8}$ and by Pliny, ${ }^{9}$ but the character of their material is doubtful. Analyses by the Gladstones ${ }^{10}$ indicated that material from Hove, near Brighton, was a hydrous aluminum oxide with accessory clay material giving a small but variable amount of silica. Optical and $\mathrm{X}$-ray examinations of a sample of so-called "collyrite" from the Fichtelgebirge show that this

3 Dana, E. S., Descriptive mineralogy, 6th ed., p. 68, 1909.

${ }^{4}$ Kirwin, Richard, Elements of mineralogy, 2d ed., vol. 1, p. 184, 1794. Haüy, R. J., Traitê de minéralogie, vol. 4, p. $444,1801$. Breithaupt, August, Handbuch der Mineralogie, vol. 2, p. 544, 1844. Thomson, Thomas, Outlines of mineralogy, geology, and mineral analysis, vol. 1, p. 246, 1836.

${ }^{5}$ Kerr, P. F., Montmorillonite or smectite as constituents of bentonite: Am. Mineralogist, vol. 17, pp. 192-198, 1932.

${ }^{6}$ Cox, E. T., Indiana Geol. Survey 5 th Ann. Rept., for 1873 , p. 15 , Indianapolis, 1874

7 Cox, E. T., Indiana Geol. Survey 7th Ann. Rept., for 1875 , p. 154, Indianapolis, 1876.

${ }^{8}$ Dioscorides, Pedacius, Materia medica, book 5, p. 151, 50 A.D.

9 Plinius, Caius, Historia naturalis, book 35, p. 16, 77 A.D.

${ }^{10}$ Gladstone, J. H. and G., On collyrite and a native carbonate of alumina and lime: Philos. Mag., vol. 23, pp. 461-466, 1862. material is kaolinite. It therefore seems probable that the name "collyrite" represents no definite mineral and should be dropped by mineralogists, although it would be desirable to retain a name that goes back to the time of Pliny if the material to which it was applied could be definitely identified.

Lenzenite was first described by John ${ }^{11}$ from Kall, in Eifel, and the examination of material from this locality (though not definitely type material) shows that it is dominantly kaolinite.

Galapectite from Anglar, France, the type locality, ${ }^{12}$ is montmorillonite, as shown by the optical properties. X-ray diffraction patterns of galapectite also agree with patterns of the type montmorillonite.

"Bole" (bolus) was a term applied to clay materials which found an application in medicine and whose use goes back to times of antiquity. Obviously the name was used for materials of varying character, but more recently it has been applied to earthy, nearly amorphous clay materials colored brown, red, or yellow by iron oxides. Some of these have been identified as impure halloysite.

\section{TYPES}

In general there are two types of halloysite-one that is usually white or light-colored, porous, friable, or almost cottony in texture; and another that is dense, nonporous, and porcelainlike. The reason for this difference has not been determined, for the optical, chemical, and X-ray properties appear to be identical. The colors of the porcelain-like material are white, light gray, buff, or faun for the purer types, and brownish or reddish for those containing iron oxides.

The white or nearly white halloysite associated with kaolin deposits (commonly those of the residual type) is difficult to distinguish from very fine grained kaolinite, and both types of material may be associated with the coarser-grained, obviously crystalline kaolinite.

Halloysite does not appear to be an abundant constituent of sedimentary beds, although it may result from the local alteration of such beds. Kaolinite appears to be much more abundant and in regions of profound weathering forms extensive deposits, but even kaolinite forms but a small fraction of the clay material of sedimentary rocks. Some of the clays similar to montmorillonite or beidellite and a sedimentary alkali-bearing clay mineral are much more abundant.

\section{CHEMICAL COMPOSITION}

Analyses have been made on 12 samples of halloysite from widely separated localities. Standard analytical methods were used and need no discussion.

${ }^{11}$ John, J. F., Chemische Untersuchungen: Chem. Schrift., vol. 5, p. $193,1816$.

${ }^{12}$ Breithaupt, J. F. A., Vollständige Charakteristik des MineralSystems, 3d ed., p. 99, 1832. 
With materials as fine grained as most halloysites it is not possible to apply any treatment to remove impurities. For that reason nearly all the samples analyzed represent material that occurs naturally in a perfectly homogeneous and apparently pure condition. Only one sample, that from Franklin, N.C., was washed and decanted to remove associated kaolinite and muscovite.
The following table gives the results of the chemical analyses. This table and the table on page 138, which gives the optical properties, are so arranged that the numbers in the two tables apply to the same samples. For this reason no. 1 is omitted in the subjoined table, as no chemical analysis is available. A detailed description of the specimen is given in connection with the table on page 138.

Chemical analyses of halloysite

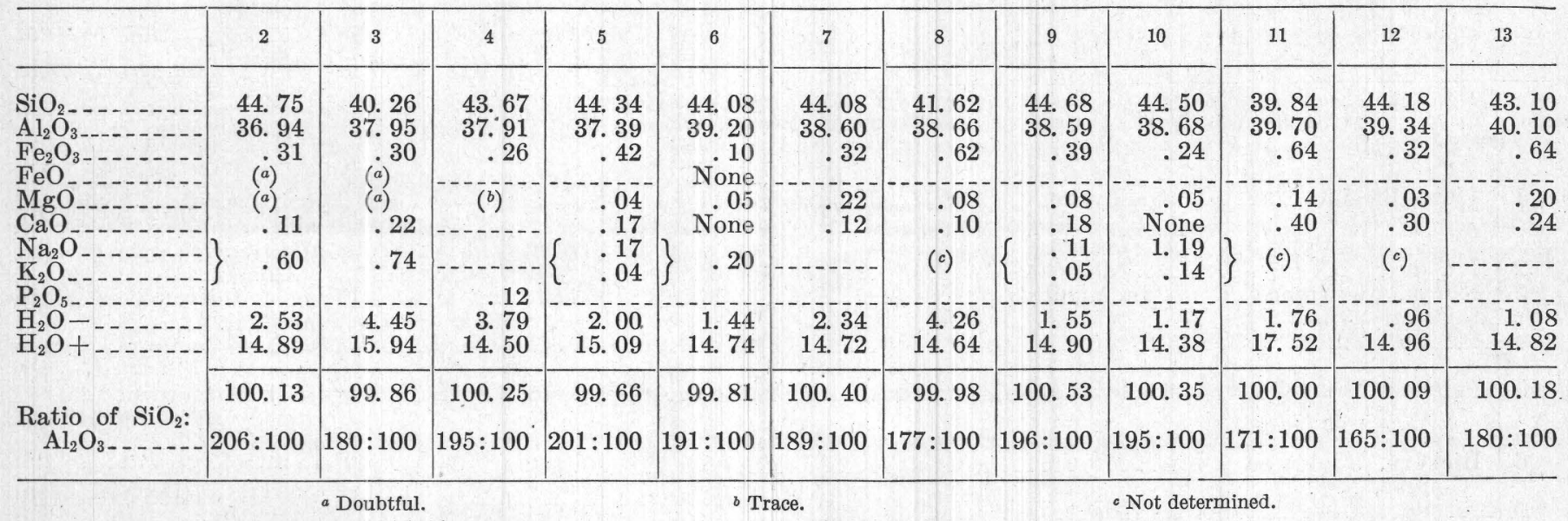

2. Liege, Belgium. Analyst, L. T. Richardson.

3, 4. Huron County, Ind. Analyst, L. T. Richardson.

5. Peppers, N.C. Analyst, E. T. Erickson.

6. Hickory, N.C. Analyst, J. G. Fairchild.

7. Hickory, N.C. Analyst, IF. A. Gonyer.

8. Adams County, Ohio. Analyst, F. A. Gonyer.

The silica-alumina ratios in the halloysites represented in the preceding table range from 206:100 to 165:100. Six samples have a ratio between 191:100 and 206:100 and an average of 197:100 or close to $2: 1$. The other six samples show a ratio between $165: 100$ and $189: 100$, and an average of $177: 100$. The average for the entire group of analyses is 187:100. The generally accepted ratio for halloysite is $\mathrm{Al}_{2} \mathrm{O}_{3}: \mathrm{SiO}_{2}: \mathrm{H}_{2} \mathrm{O}=1: 2: 2 .{ }^{13}$

The rather large and systematic deviation of the silica-alumina ratio from the ratio $2: 1$ in so large a number of apparently pure samples demands consideration. The alumina is a little higher than the accepted ratio in most of the samples, and this suggests at first that they may have contained a slight excess of some aluminous mineral. However, optical and Xray studies prove that they contained practically no crystalline impurities, and the only possible explanation would be the presence of noncrystalline material. Such a material forming an amorphous matrix around crystalline grains would be expected to cause induration of the material. However, the compact, porcelainlike samples approach more nearly the ideal com-

${ }^{13}$ LeChatelier, H., De l'action de la chaleur sur les argiles: Soc. française minéralogie Bull., vol. 10, pp. 204-211, 1887.
9. Brandon, Rankin County, Miss. Analyst, Charles Milton. 10. Leakey, Real County, Tex. Analyst, R. K. Bailey.

11. Sneeds Creek, Newton County, Ark. Analyst, F. A. Gonyer. 12. Franklin, N.C. Analyst, F. A. Conyer.

13. Myeline, Saxony. Analyst, F. A. Gonyer.

position than those with a friable chalky texture. The average ratio of 8 porcelainlike samples is 191:100; that of the chalky samples is 179:100.

A comparison of the analyses of halloysite with those of kaolinite ${ }^{14}$ indicates that halloysite tends to be richer in alumina than kaolinite-that is, kaolinite tends to be somewhat closer to the ideal formula $2 \mathrm{H}_{2} \mathrm{O} \cdot \mathrm{Al}_{2} \mathrm{O}_{3} \cdot 2 \mathrm{SiO}_{2}$ than halloysite, although anauxite, the high-silica end member of the anauxite-kaolinite group, has a silica ratio of $3: 1$. Taking the anauxitekaolinite series and halloysite together, we have a variation in the silica-alumina ratio from $294: 100$ to $165: 100$. The sample from Franklin, N.C., with the ratio $165: 100$, corresponds closely with the ratio $3: 2$, which has been assigned to pholerite, ${ }^{15}$ a crystallized clay mineral described by Guillemin ${ }^{16}$ in 1825 . This formed hexagonal plates and so probably belongs to the kaolinite series. However, a member with this ratio seems probable and might belong to either the anauxite-kaolinite or the halloysite series, and the high alumina in many samples of halloysite makes it seem

14 Ross, C. S., and Kerr, P. F., op. cit., p. 163.

15 Ries, Heinrich, Clays; their occurrence, properties, and uses, $3 \mathrm{~d}$ ed., p. 81, New York, John Wiley \& Sons, 1927.

${ }_{16}$ Guillemin, J., Note sur la pholérite: Annales des mines, vol. 11, p. 489,1825 . 
probable that such a molecule forms part of a halloysite series.

Consideration of the variable silica-alumina ratio in carefully selected and analyzed kaolinite and anauxite led to the conclusion that this was probably not due to impurities but was the result of a truly variable ratio between the two end members, ${ }^{17}$ the valence requirements being satisfied by a variation in the number of the hydrogen atoms. If this is so, the

${ }^{17}$ Ross, C. S., and Kerr, P. F., op. cit., p. 165. material with the lower silica would have the higher water content. This inference is partly confirmed by the fact that the water ratio is distinctly higher in the analyses with a silica-alumina ratio below 180:100 than in those in which the ratio is between 191:100 and $206: 100$.

\section{OPTICAL PROPERTIES}

The optical properties of 20 samples of halloysite are given in the following table:

Optical and physical properties of halloysite

\begin{tabular}{|c|c|c|c|c|c|c|c|}
\hline No. & Locality & Name & Texture & Color & $\begin{array}{l}\text { Index of } \\
\text { refraction }\end{array}$ & Birefringence & Remarks \\
\hline 1 & Liege, Belgium & Halloysite & Porcelainlike_- & Pale blue_. & 1. 552 & None & $\begin{array}{l}\text { Type locality. Associated } \\
\text { with alunite, allophane, } \\
\text { gibbsite. }\end{array}$ \\
\hline 3 & $\begin{array}{l}\text { Huron, Lawrence } \\
\text { County, Ind. }\end{array}$ & "Indianaite" & $=-\mathrm{do} \mathrm{O}_{-}$ & & $\begin{array}{l}\text { 1. } 546 \\
1.546\end{array}$ & $\begin{array}{l}\text { Slight } \\
- \text { do }\end{array}$ & $\begin{array}{l}\text { Do. } \\
\text { Type locality. Very clean } \\
\text { material. }\end{array}$ \\
\hline 4 & - do & & & Pale buff_ & 1. 552 & None_- & $\begin{array}{l}\text { Associated with phosphate } \\
\text { mineral. }\end{array}$ \\
\hline 5 & $\begin{array}{l}\text { Peppers, Mitchell } \\
\text { County, N.C. }\end{array}$ & Halloysite_. & $\ldots \mathrm{do}_{-}$ & White__. & 1. 551 & Slight & $\begin{array}{l}\text { S mall flattened nodules } \\
\text { coated with ferruginous }\end{array}$ \\
\hline 6 & $\begin{array}{l}\text { Hickory, Catawba } \\
\text { County, N.C. }\end{array}$ & -...do_- & Chalky_- & & 1. 552 & & $\left\{\begin{array}{l}\text { Contains a little mica and } \\
\text { quartz. }\end{array}\right.$ \\
\hline 8 & Adams County, Ohio & & Porcelainlike & Pale buff & $\begin{array}{l}\text { 1. } 551 \\
\text { 1. } 550\end{array}$ & & $\begin{array}{l}\text { pegmatite. } \\
\text { Variable in character, but }\end{array}$ \\
\hline 9 & $\begin{array}{l}\text { Bradon, Rankin County, } \\
\text { Miss. }\end{array}$ & do & $\ldots \mathrm{do}_{-}$ & White... & 1. 548 & & $\begin{array}{l}\text { best lumps very pure. } \\
\text { Very pure material. }\end{array}$ \\
\hline 10 & $\begin{array}{l}\text { Leakey, Real County, } \\
\text { Tex. }\end{array}$ & $\ldots d$ & Chalky & & 1. 559 & $-\mathrm{do}_{-}$ & $\begin{array}{l}\text { Some specimens contain al- } \\
\text { unite. }\end{array}$ \\
\hline 11 & $\begin{array}{l}\text { Sneeds Creek, Newton } \\
\text { County, Ark. }\end{array}$ & "Newtonite" - & & & 1. 552 & $-\mathrm{do}_{-}$ & $\begin{array}{l}\text { Halloysite and alunite. Type } \\
\text { locality. }\end{array}$ \\
\hline 12 & Franklin, N.C & "Kaolin"- & & & 1. 556 & None_ & Admixed with kaolinite and \\
\hline 13 & $\begin{array}{l}\text { Myeline, Rochlitz, Sax- } \\
\text { ony. }\end{array}$ & "Lithomarge". & Porcelainlike_- & -...-do_. & 1. 558 & Slight_ & $\begin{array}{l}\text { Botryoidal masses coated } \\
\text { with iron-stained halloy- }\end{array}$ \\
\hline 14 & Bergnersruth, Bavaria_- & "Glagerite" - & & Cream. & 1. 552 & & $\begin{array}{l}\text { site. } \\
\text { Drusy cavities contain kao- }\end{array}$ \\
\hline 15 & $\begin{array}{l}\text { Maiden, Catawba } \\
\text { County, N.C. }\end{array}$ & Halloysite_. & Chalky & White_. & 1. 551 & & $\begin{array}{l}\text { linite. } \\
\text { and quartz. Derived from }\end{array}$ \\
\hline 16 & Hillsboro, Highland & & Porcelainlike & Light gray & 1. 543 & & $\begin{array}{l}\text { pegmatite. } \\
\text { Associated with an impure } \\
\text { ferruginous clay. }\end{array}$ \\
\hline $\begin{array}{l}17 \\
18\end{array}$ & $\begin{array}{l}\text { Hart County, Ky } \\
\text { Cordillera of Peru...-..- }\end{array}$ & \begin{tabular}{l} 
L do do \\
\hdashline.--1 do
\end{tabular} & $\begin{array}{l}\text { Chalky } \\
\text { Porcelainlike }\end{array}$ & Light fau & $\begin{array}{l}\text { 1. } 561 \\
\text { 1. } 552\end{array}$ & Non & $\begin{array}{l}\text { Contains some alunite. } \\
\text { Very pure. }\end{array}$ \\
\hline 19 & Alban, Tarn, France & - do & Compact_- & Dark red_. & 1. 648 & & $\begin{array}{l}\text { Shows sedimentary bedding } \\
\text { planes and contains iron }\end{array}$ \\
\hline 20 & $\begin{array}{l}\text { Rolla, Phelps County, } \\
\text { Mo. }\end{array}$ & "Flint clay" & & Nearly white_ & 1. 567 & & $\begin{array}{l}\text { oxide. } \\
\text { Contains some kaolinite. }\end{array}$ \\
\hline 21 & Lookout, Ala_........ & Halloysite & Porcelainlike_ & Gray & 1. 555 & $\ldots d$ & Do. \\
\hline 22 & Fichtelgebirge, Bavaria_- & "Collyrite" & Compact_... & Pale faun.... & 1. 558 & $\ldots$ do_. & Botryoidal surfaces, com- \\
\hline 23 & $\begin{array}{l}\text { Saszka Bunat, Hun- } \\
\text { gary. }\end{array}$ & "Lithomarge" - & -do & $\mathrm{d}$ & 1. 554 & $\ldots$ do & Botryoidal surfaces. \\
\hline
\end{tabular}

1, 2. From Angleur, Liege, Belgium. No. 1 is light sky-blue, and no. 2 is nearly pure white. It forms small irregular ironstained lumps, but by hand picking pure clean material was selected. Porcelainlike in texture and shows conchoidal fracture. Occurs in limestone in the vicinity of iron and zinc mines.

3 , 4. Pure white; with conchoidal fracture. The outer surfaces are iron-stained, and small cavities contain manganese oxide, which were completely removed by hand picking. Occurs at the contact between Chester shales (Mississippian) and the Mansfield sandstone (Pennsylvanian). ${ }^{18}$

5. Forms small irregular lenses 2 centimeters or more across in a region of altered igneous and metamorphic rocks. The

${ }^{18}$ Logan, W. N., Economic geology of Indiana : Indiana Dept. Conservation Pub. 21, p. 672, 1922. 
outer coating is iron-stained, but the material is pure white below the surface. It has conchoidal fracture.

6, 7. Friable, with an almost talcose feel.

8. Conchoidal fracture. Dr. Walter Bucher, who collected the material, has kindly supplied the following description of its occurrence: ${ }^{10}$

"White fragments of halloysite occur in nearly circular areas at three places near the borders of the cryptovolcanic area in Adams and Highland Counties, Ohio. In one locality a gully has cut into the mass, showing that the pure halloysite is only a few inches in thickness and grades downward into a mixture of halloysite and clay where it fills pores of fragments that are residual after dolomite. Traces of halloysite form rather widely distributed iron-stained gray masses of clayey material, which occur along the contact of the black Ohio shale with the underlying Silurian dolomites. Commonly only isolated fragments are seen, which appear waxy when taken freshly from the ground. Upon drying these crack into the familiar white or light-colored angular fragments, which take a high polish when rubbed."

9. One mile east of Bradon, Miss. Irregular nodules, with an iron-stained coating.

10. Six miles west of Leakey, Tex., in the Edwards Plateau region. The following description of the occurrence has been supplied by Dr. R. F. Ryan, of the Vacuum Oil Co., Houston, Tex. : ${ }^{20}$

"The material has been penetrated to a depth of 130 feet in one shaft and has been found to occur over an area of approximately 320 acres. The formations which outcrop around this deposit are Edwards limestone, Comanchean age, Fredericksburg division. The material lies below the limestone, but a siliceous mass associated with the kaolinitic material contains chert fragments." Most of the samples from this locality are very fine-grained kaolinite, but a few are very pure halloysite.

11. Halloysite (originally described as newtonite ${ }^{21}$ ). The occurrence and location given below are taken from a description by Wherry. ${ }^{22}$

"The locality is situated in the Harrison quadrangle, about 4 miles west of Compton in the gorge of Sneed's Creek. The material was collected from a group of small prospect pits in decomposed shale which carried small lumps of soft white chalky material, more or less stained by iron oxides."

After chemical and optical studies, Foshag ${ }^{23}$ concluded that in the original study by Brackett and Williams the optical determinations had been made on alunite and the analysis on halloysite.

12. Halloysite, about 4 miles north of Franklin, N.C., where it forms an isotropic matrix around tiny kaolinite crystals in a kaolin deposit resulting from the weathering of a pegmatite. Halloysite separated from kaolinite by washing.

13. Halloysite ("kaolinite"). Occurs in irregular ironstained lumps a few centimeters in diameter.

14. Halloysite. Dense material, containing a few irregular cavities with chalky-white coatings.

15. Creamy-white, soft mass.

16. Light-gray porcelainlike masses.

17. Light-gray chalky masses.

19 Personal communication.

${ }^{20}$ Personal communication. See also Ries, Heinrich, The clays of Texas: Texas Univ. Bull. 102, Sci. ser., vol. 2, pp. 82-84, 1908.

${ }^{21}$ Brackett, R. N., and Williams, J. F., Newtonite and rectorite, two new minerals of the kaolinite group: Am. Jour. Sci., 3d ser., vol. 42 , pp. 11-21, 1891.

${ }_{22}$ Wherry, E. T., A visit to the locality of newtonite: Am. Mineralogist, vol. 10, pp. 350-351, 1925.

${ }^{23}$ Foshag, W. F., The identity of newtonite with alunite: Am, Mineralogist, vol. 11, pp. 33-35, 1926.
18. Exact locality unknown.

19. Soft material that contains much iron oxide. The $\mathrm{X}$ ray diffraction pattern of this sample is weak, even for a pattern of halloysite, and suggests the presence of elements having higher absorption for X-rays. Mixed hydrous iron oxide could account for the unusually high index of refraction.

20. Associated with diaspore.

21. Conchoidal fracture.

22, 23. Relations unknown.

It is possible to determine only one index of refraction of halloysite, because much of the material is completely isotropic, and the remainder has a birefringence of 0.001 or less. The cause of this faint birefringence is not entirely clear. Some of it may be due to very slight strain, but it seems probable that a very fine mottled gray effect just within the powers of resolution of the microscope is a real birefringence due to a partly oriented aggregate of birefracting mineral grains of submicroscopic size. The X-ray studies described on page 141 show that halloysite is truly crystalline and closely related to other minerals of the kaolin group. As it is so closely related to these minerals it is probably not isotropic and so has a birefringence that is usually not observable because the unoriented grains are smaller than the powers of resolution of the microscope. However, all the other members of the kaolin group have a birefringence of about 0.006 to 0.007 , and it seems probable that two minerals so closely related in chemical composition, mean index of refraction, and character of space lattice as kaolinite and halloysite would have approximately the same birefringence.

The optical properties of halloysites given in the table show some variation. The index of refraction of no. 19, from Alban, France, is abnormally high, owing to the presence of iron oxide, but the 22 others show a variation between 1.543 and 1.567 , and 11 of these have indices between 1.551 and 1.556. The mean of the entire series is 1.5527 . The variation is due, in part at least, to the variation in water content, discussed on page 140. The average for the $\beta$ index of refraction of 16 samples of kaolinite ${ }^{24}$ is 1.5647 , showing that kaolin averages 0.012 higher than halloysite in index of refraction. This is due, at least in part, to the higher water content of halloysite but is probably due in part to inherent crystallographic differences.

\section{DEHYDRATION}

Dehydration tests have been made on three typical samples of halloysite. Two of these-one from Adams County, Ohio, and one from Liege, Belgium - were of the dense, porcelainlike type, and the other, from Hickory, N.C., was of the chalky type. The Hickory sample has a lower total water content than the other two, but the analyses given in the table on page 137

${ }^{24}$ Ross, C. S., and Kerr, P. F., op. cit., p. 162. 
indicate that this difference is not a characteristic of the group as a whole.

Dehydration temperatures of halloysite

\begin{tabular}{|c|c|c|c|c|c|}
\hline \multicolumn{2}{|c|}{ Ohio } & \multicolumn{2}{|c|}{ Belgium } & \multicolumn{2}{|c|}{ North Carolina } \\
\hline Temperature & Loss of water & $\begin{array}{c}\text { Tempera- } \\
\text { ture }\end{array}$ & Loss of water & $\begin{array}{l}\text { Tempera- } \\
\text { ture }\end{array}$ & Loss of water \\
\hline $\begin{array}{r}{ }^{\circ} \mathrm{C} . \\
105 \\
150 \\
240 \\
300 \\
350 \\
375 \\
410 \\
450 \\
485 \\
525 \\
560 \\
600 \\
650 \\
700 \\
\text { Ignition }\end{array}$ & $\begin{array}{r}\text { Percent } \\
4.72 \\
5.10 \\
5.20 \\
5.37 \\
6.00 \\
6.03 \\
6.40 \\
14.23 \\
15.82 \\
17.42 \\
17.70 \\
17.86 \\
18.16 \\
18.53 \\
19.13\end{array}$ & $\begin{array}{r}{ }^{\circ} \mathrm{C} . \\
\text { Room } \\
55 \\
135 \\
145 \\
240 \\
260 \\
340 \\
390 \\
435 \\
475 \\
515 \\
555 \\
620 \\
740 \\
850\end{array}$ & $\begin{array}{r}\text { Percent } \\
0.00 \\
2.60 \\
3.83 \\
4.39 \\
4.67 \\
4.92 \\
5.82 \\
5.56 \\
7.12 \\
14.02 \\
18.91 \\
19.53 \\
20.17 \\
20.78 \\
21.10\end{array}$ & $\begin{array}{l}{ }^{\circ} \mathrm{C.} \\
110 \\
160 \\
200 \\
250 \\
300 \\
350 \\
400 \\
450 \\
500 \\
550 \\
600 \\
650 \\
700 \\
800\end{array}$ & $\begin{array}{r}\text { Percent } \\
1.44 \\
1.47 \\
2.10 \\
2.54 \\
2.68 \\
2.98 \\
3.86 \\
6.72 \\
14.32 \\
15.32 \\
15.52 \\
16.01 \\
16.18 \\
16.22\end{array}$ \\
\hline
\end{tabular}

Curves plotted from this table and from data on kaolinite from Ione, Calif.; dickite from Cusihuiriachic, Chihuahua, Mexico; and nacrite from Brand, Saxony, ${ }^{25}$ are given in figure 6.

The dehydration curves of halloysite show that there is a very gradual loss of water up to a temperature of about $400^{\circ}$ to $430^{\circ} \mathrm{C}$., where there is a break in the curves, and a rapid loss of water up to a temperature of about $500^{\circ}$, after which there is a rapid flattening of the curve. The dehydration curves tend to flatten at $200^{\circ}$, but if this has any real significance the reason is not apparent. It is quite evident that the water lost up to $110^{\circ}$ (1.44 to 4.75 percent) is not significant but represents adsorbed water. In fact the water lost up to $200^{\circ}$ (2.5 to 5.20 percent) is no doubt adsorbed.

It is to be expected that material made up of submicroscopically crystalline particles would have a

${ }^{25}$ Ross, C. S., and Kerr, P. F., op. cit., p. 166.

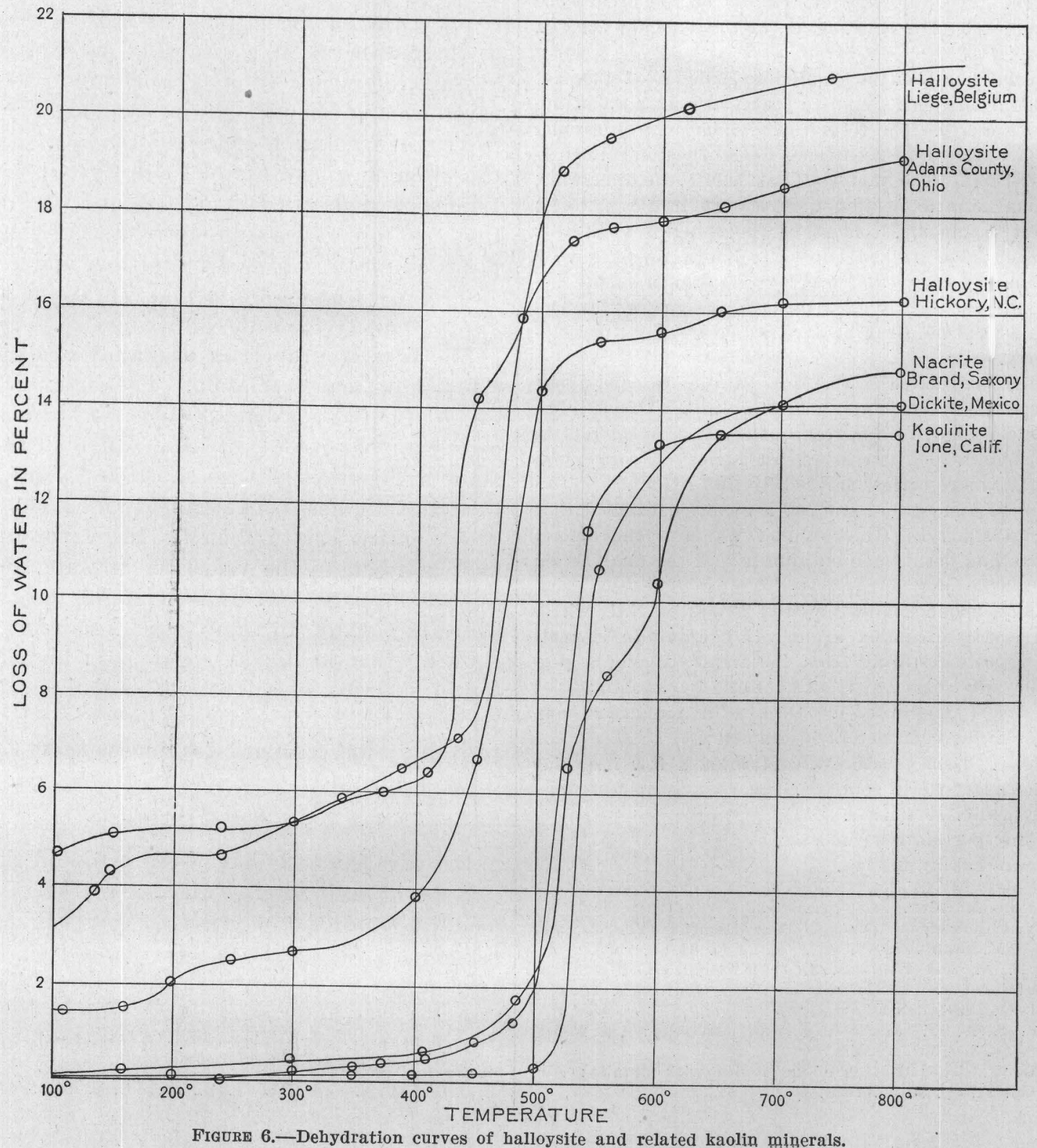




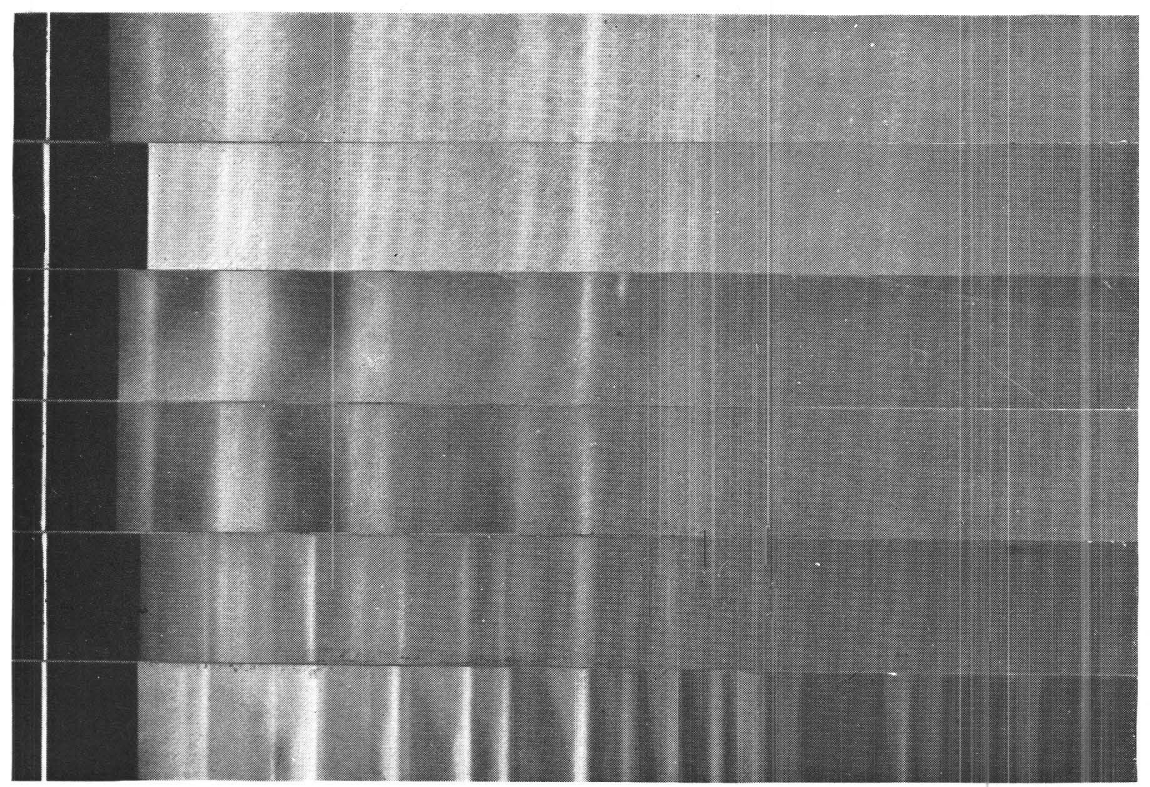

$$
\begin{aligned}
& \text { Halloysite (white) } \\
& \text { Liege, Belgium } \\
& \text { Halloysite } \\
& \text { Adams Co., Onio }
\end{aligned}
$$

\section{Halloysite Adams Co., Ohio}

\section{Halloysite \\ Cordillera of Peru}

\section{Halloysite \\ Nevada}

Halloysite and alunite Edwards Plateau, Tex.

\section{Alunite \\ Japan}

A. X-RAY DIFFRACTION PATTERNS OF HALLOYSITE FROM SEVERAL LOCALITIES.

A pattern of halloysite mixed with alunite is also shown, and a pattern of alunite for comparison.

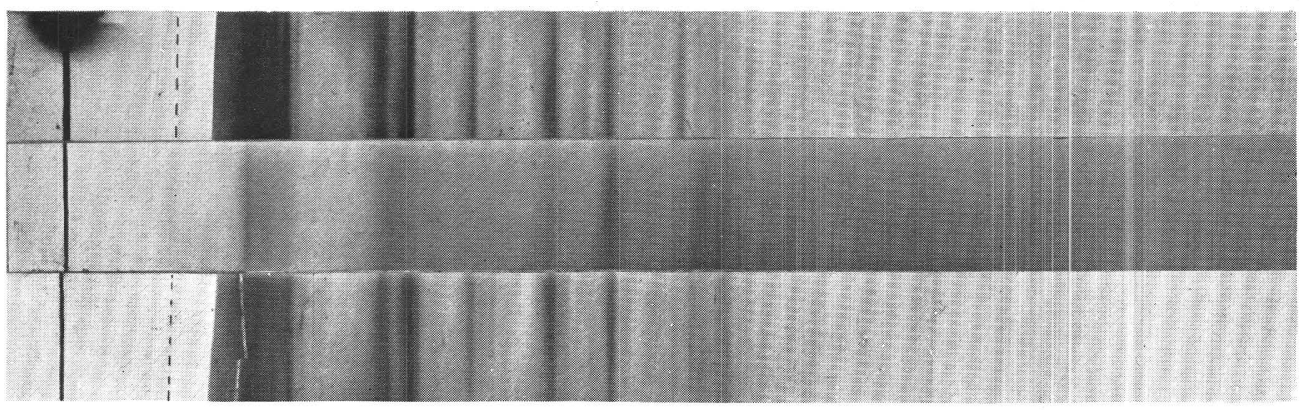

\section{Dickite \\ Greenwood, Ark.}

Halloysite (white)

Liege, Belgium

\section{Kaolinite}

Brooklyn, N.Y.

B. X-RAY DIFFRACTION PATTERNS OF DICKITE AND KAOLINITE COMPARED WITH HALLOYSITE.

The dotted line indicated near the zero beam for dickite and kaolinite was masked by the shield of the casette. 


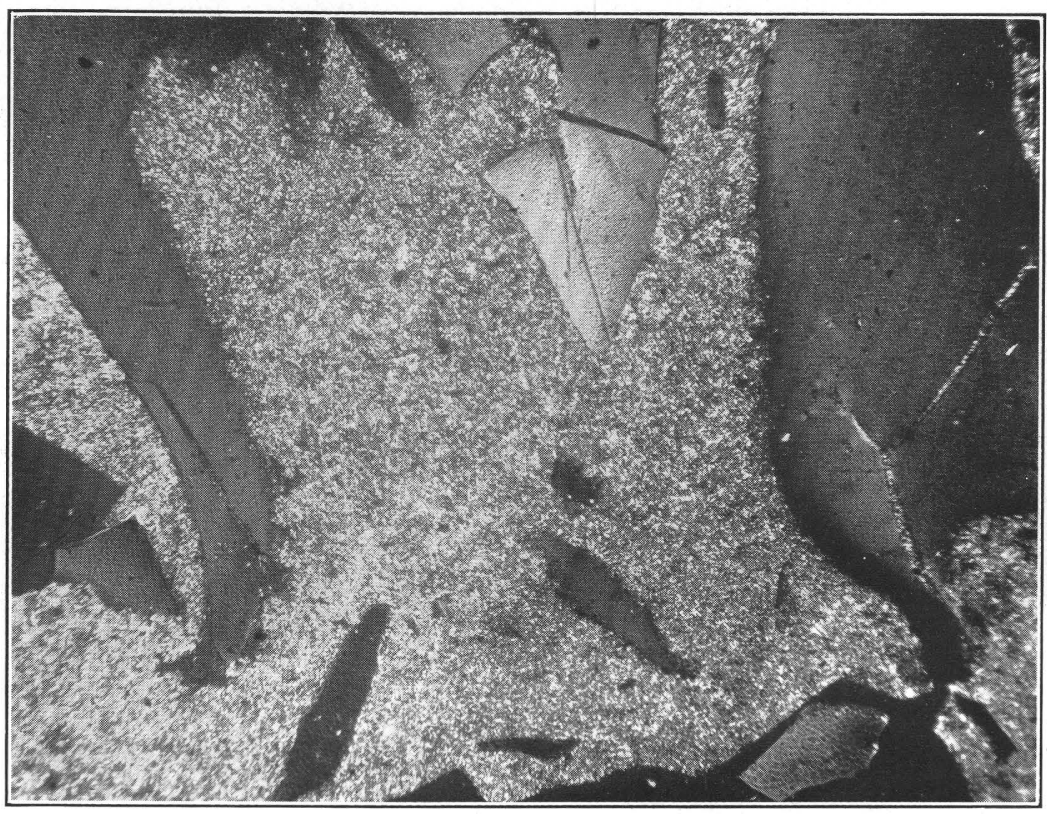

A. PHOTOMICROGRAPH OF HALLOYSITE AND ALUNITE FROM VICINITY OF HURON, IND.

The nearly isotropic areas are halloysite, and the intermediate finely crystalline material is alunite. Crossed nicols, $\times$ about 27 .

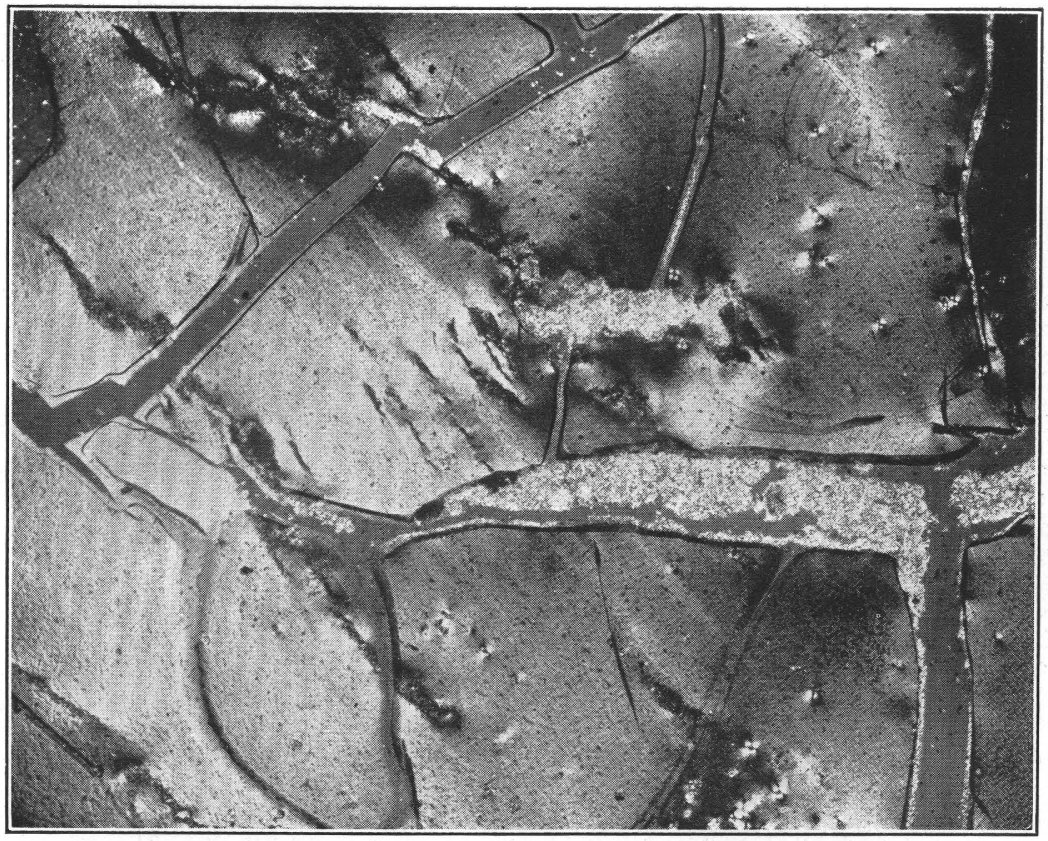

B. PHOTOMICROGRAPH OF PORGELAINLIKE INDIANAITE SHOWING HALLOYSITE WITH SHATTER CRACKS FILLED WITH ALUNITE. The halloysite mass contains small spherulitic areas, which, to judge from the $\mathrm{X}$-ray lines, are gibbsite. Crossed nicols, $\times$ about 27 . 
rather large content of adsorbed water and that part of this should be held rather tenaciously. The very perfectly crystalline dickite, on the other hand, loses no water at $110^{\circ}$ and only 0.12 percent up to $450^{\circ}$. The essential, high-temperature water of halloysite is evidently that lost between $400^{\circ}$ (or perhaps $250^{\circ}$ ) and complete dehydration. It is interesting to note that X-ray diffraction patterns of samples used for dehydration show a loss of lines between $450^{\circ}$ and $500^{\circ} \mathrm{C}$. It appears, therefore, that the break in the curve is accompanied by a loss of crystallinity.

The dehydration curves for the other minerals of the kaolin group-kaolinite, dickite, and nacrite-incicate a distinctly higher temperature stability than that of halloysite. The lower break in the curves of kaolinite and nacrite, where a distinct loss of water begins, is at about $490^{\circ}$, and for dickite at about $510^{\circ}$. That is, halloysite begins to break down at $60^{\circ}$ to $80^{\circ}$ lower temperature than the other minerals of the kaolin group.

The region between 4 and 3.4 angstrom units is most critical with molybdenum radiation, in distinguishing between halloysite and kaolinite. Three broad and diffused lines occur in this portion of the pattern of halloysite, whereas five sharper lines occur in the same region in the pattern of kaolinite. The comparative interplanar spacings and estimated relative intensities of the two patterns for this region are as follows:

Comparative interplanar spacings of halloysite and kaolinite

\begin{tabular}{|c|c|c|c|}
\hline \multicolumn{2}{|c|}{ Falloysite } & \multicolumn{2}{|c|}{ Kaolinite } \\
\cline { 1 - 3 } $\begin{array}{c}\text { Estimated } \\
\text { relative } \\
\text { intensity }\end{array}$ & $\begin{array}{c}\text { Spacing (ang- } \\
\text { strom units) }\end{array}$ & $\begin{array}{c}\text { Estimated } \\
\text { relative } \\
\text { intensity }\end{array}$ & $\begin{array}{c}\text { Spacing (ang- } \\
\text { strom units) }\end{array}$ \\
\hline 10 & 4.42 & 10 & 4.464 \\
5 & 3.97 & 10 & 4.194 \\
6 & 3.63 & 5 & 3.874 \\
& & 6 & 3.614 \\
& & 5 & 3.424 \\
\hline
\end{tabular}

\begin{tabular}{|c|c|c|c|c|c|c|}
\hline עू & $\begin{array}{l}\text { *ै के } \\
\text { से ले }\end{array}$ & 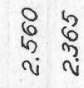 & $\stackrel{2}{8}$ & $\stackrel{?}{?}$ & 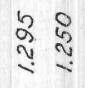 & Interplanar spacing \\
\hline 8 & 整 & 8 & , & 镸 & 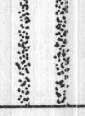 & Halloysite, normal type \\
\hline 4 & 1056 & 45 & 4 & 10 & 22 & Estimated intensity \\
\hline & & X & , & & 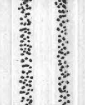 & Halloysite, Liege, Belgium \\
\hline
\end{tabular}

FIGURE 7.-X-ray diffraction pattern of halloysite. Lines 4 and 5 have a tendency to be merged together in the more firmly crystalline halloysite.

\section{X-RAY EXAMINATION}

X-ray diffraction patterns of halloysite given in plate $28, A$, typify a pattern due to finely divided crystalline material of colloidal dimensions. The diffraction lines are not sharp, like those of well-crystallized minerals, but have diffused borders, and many of the intervening spaces are darkened somewhat by general radiation. In general about 10 distinct lines appear that can be measured with fair accuracy. Other lines are usually too weak to be measured accurately. A diagram illustrating the arrangement of the diffraction lines and their corresponding interplanar spacing is shown in figure 7 .

The X-ray diffraction patterns of halloysite are related to those of kaolinite. Diffraction lines at 1.560 , $2.365,1.685,1.510,1.295$, and 1.250 angstrom units agree in intensity and spacing with lines in the X-ray diffraction pattern of kaolinite. A single isolated line at 7.42 angstrom units occurs in the $\mathrm{X}$-ray diffraction patterns of both minerals and likewise in those of nacrite, dickite, and anauxite, and this line is apparently significant for the kaolin group.
Patterns of kaolinite and halloysite given in plate $28, B$, also show differences with both iron and copper radiation. Dr. Stirling B. Hendricks, of the Fixed Nitrogen Research Laboratory, United States Department of Agriculture, has taken photographs illustrating this difference with a copper target and has furnished negatives for our comparison. Dr. E. R. Jette, of the department of mining and metallurgy, Columbia University, has furnished us with $\mathrm{X}$-ray diffraction photographs using iron radiation. The iron and copper radiations, paticularly when the $\beta$ lines of the $K$ series as well as the $\alpha$ lines are photographed, show more striking differences than are normally observed when the $K-\alpha$ radiation of molybdenum is utilized. In view of these differences in $\mathrm{X}$-ray diffraction, which imply a fundamental difference in crystallization, it appears that halloysite should be distinguished from the other members of the kaolin group. Thus, the X-ray patterns confirm the difference between kaolinite and halloysite noted in the optical examination and dehydration curves.

A system of diffused X-ray diffraction lines, such as is observed in halloysite, is to be expected in a mineral 
that is optically almost isotropic. On the other hand, as kaolinite is obviously crystalline and doubly refracting with the polarizing microscope, the X-ray diffraction lines should be the lines of a well-crystallized mineral. It is also to be noted that the mean index of refraction of kaolinite is approximately 1.565 , while the index of refraction of halloysite is approximately 1.553 . Thus the lack of agreement in refractive indices indicates a difference between the two minerals. The distinct difference in temperature stability between halloysite and the other kaolin minerals is probably more significant than the observable optical properties and tends to confirm the Xray diffraction data in indicating a distinct mineral.

X-ray diffraction patterns of halloysite from Liege differ from patterns of glassy allophane, which occurs in the same locality. The glassy allophane forms an indistinct X-ray diffraction pattern that consists of three areas of broad diffused radiation. The areas of diffused radiation, however, do not correspond to groups of lines in the halloysite pattern. Thus it does not appear that allophane is simply a finer state of subdivision of the crystal particles of halloysite but is a distinct species.

As pointed out in the foregoing discussion, differences in X-ray patterns also indicate that halloysite is not merely a finely divided kaolinite. All the samples of halloysite examined, however, have been composed of very finely divided material, and it has not yet been determined whether a more coarsely crystalline compound would crystallize as halloysite or would form kaolinite. Experience thus far indicates that the more coarsely crystalline material is kaolinite or anauxite.

As a result of optical studies, halloysite has been considered an amorphous mineral by Rogers, ${ }^{26}$ who calls it the amorphous equivalent of kaolinite. X-ray data would indicate, however, that the mineral has definitely discontinuous vectorial properties, one of the considerations emphasized by Rogers in distinguishing amorphous minerals; hence it should not properly be called amorphous. It should be pointed out, on the other hand, that halloysite occupies a state of crystallinity intermediate between the microcrystalline particles of kaolinite and the finely divided, almost completely dispersed allophane. Wherry ${ }^{27}$ has proposed the grouping of minerals into crystals, metacolloids, and colloids. Halloysite probably belongs to the colloidal group of Wherry ${ }^{28}$ considered with reference to particle size.

\footnotetext{
${ }^{26}$ Rogers, A. F., A review of the amorphous minerals : Jour. Geology, vol. 25, p. $555,1917$.

${ }^{27}$ Wherry, E. T., Variations in the compositions of minerals : Washington Acad. Sci. Jour., vol. 4, p. 112, 1914.

${ }^{28}$ Wherry, E. T., A tabulation of the aluminum silicate minerals: Am. Mineralogist, vol. 10 , no. 6, p. 143,1925 .
}

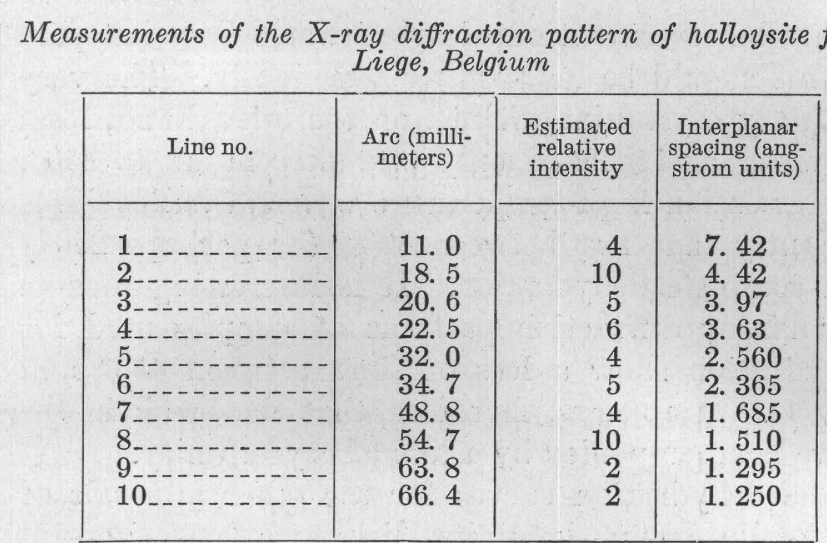

Record of $X$-ray diffraction patterns

\begin{tabular}{|c|c|c|}
\hline No. & Locality & $\begin{array}{l}\text { Minerals present in clay as shown } \\
\text { by X-ray patterns }\end{array}$ \\
\hline 1,2 & Liege, Belgium & \multirow{2}{*}{$\begin{array}{l}\text { Halloysite plus allophane, } \\
\text { gibbsite, alunite. } \\
\text { Do. }\end{array}$} \\
\hline 3,4 & $\begin{array}{l}\text { Huron, Lawrence County, } \\
\text { Ind. }\end{array}$ & \\
\hline 5 & $\begin{array}{l}\text { Peppers, Mitchell County, } \\
\text { N.C. }\end{array}$ & Halloysite. \\
\hline 6,7 & $\begin{array}{l}\text { Hickory, Catawba County, } \\
\text { N.C. }\end{array}$ & Halloysite plus kaolinite. \\
\hline $\begin{array}{r}8 \\
10\end{array}$ & $\begin{array}{l}\text { Adams County, Ohio } \\
\text { Leakey, Real County, Tex.: }{ }^{a}\end{array}$ & \multirow{3}{*}{$\begin{array}{l}\text { Halloysite. } \\
\text { Do. } \\
\text { Halloysite plus alunite. } \\
\text { Do. }\end{array}$} \\
\hline 11 & $\begin{array}{l}\text { Isotropic } \\
\text { Partly isotropic }\end{array}$ & \\
\hline 11 & $\begin{array}{l}\text { sneeds Creek, Newton coun- } \\
\text { ty, Ark. ("newtonite"). }\end{array}$ & \\
\hline 13 & $\begin{array}{l}\text { Rochlitz, Saxonya ("litho- } \\
\text { marge") }\end{array}$ & \multirow{6}{*}{$\begin{array}{l}\text { Halloysite. } \\
\text { Do. } \\
\text { Do. } \\
\text { Halloysite plus alunite. } \\
\text { Halloysite. } \\
\text { Do. } \\
\text { Halloysite plus kaolinite. } \\
\text { Do. }\end{array}$} \\
\hline 14 & $\begin{array}{l}\text { Bergnersruth, Bavaria " ("gla- } \\
\text { gerite"). }\end{array}$ & \\
\hline $\begin{array}{l}16 \\
17\end{array}$ & o, Ohio & \\
\hline 18 & llera of Peru & \\
\hline 19 & , Tarn, France ${ }^{b}-$ & \\
\hline $\begin{array}{l}20 \\
21\end{array}$ & $\begin{array}{l}\text { Rolla, Mo. }{ }^{a} \text { (flint clay) -- } \\
\text { Lookout, }{ }^{a} \text { Ala_. }\end{array}$ & \\
\hline & & \\
\hline
\end{tabular}

${ }_{a}^{a}$ Halloysite from these localities contains impurities visible with a microscope but

causing no apparent effect on the X-ray pattern.
$b$ Contains visible iron oxide.

\section{MODE OF OCCURRENCE}

Halloysite is very commonly associated with kaolinite in some kaolin deposits, especially in residual deposits derived from pegmatite. Here the relations of the two minerals indicate that the first clay mineral to form is commonly halloysite and that kaolinite is the result of its recrystallization. Halloysite also occurs together with allophane in some deposits in such a way as to indicate that it has resulted from the crystallization of that mineral, although it is improbable that all halloysite has formed in this manner. Other specimens form lenslike masses in fractures in rock, suggesting that the halloysite has been precipitated from solution.

\section{ASSOCIATED MINERALS}

Alunite has been found associated with halloysite, studied in the preparation of this report, in specimens 
from five localities-Liege, Belgium; Lawrence County, Ind.; Newton County, Ark. (pl. 29, A) ; Hart County, Ky.; and Leakey, Real County, Tex. It probably also occurs along with halloysite elsewhere. In each of the five localities mentioned specimens may be obtained in which alunite is intimately mixed with halloysite as a fine-grained mixture, but halloysite free from alunite also occurs in each locality. The halloysite free from alunite is dense, usually resembling porcelain in appearance ( $\mathrm{pl} .29, B$ ), and appears almost isotropic in thin sections. White masses from Indiana or the vicinity of Liege contain contraction cracks along which finely crystalline alunite and kaolinite have penetrated, filling the cracks. In such occurrences it appears that the finely crystalline mixture represents a slightly later phase in the process of formation of the white clay, although probably not separated by a cessation of chemical action.

Allophane, discussed on page 144 , is associated with halloysite near Liege, where it occurs as a clear hyaline mass with black streaks of carbonaceous stains, and material of similar character occurs with halloysite at Huron, Ind.

Diaspore is a common associate of halloysite in the flint clays of Missouri. Excellent X-ray diffraction patterns of this mineral have been obtained from material associated with flint clay from the commercial deposits of Gasconade County.

Gibbsite has been found in association with halloysite in the specimens from Liege. An X-ray diffraction pattern of purified material agrees with X-ray patterns of gibbsite from several localities. Gibbsite has also been identified in association with indianaite by X-rays.

The association of diaspore and gibbsite with halloysite under certain circumstances may account for some of the variations in chemical analyses. It is also further evidence in support of the origin of halloysite as a result of weathering.

\section{ORIGIN}

Halloysite appears to be the result of supergene processes; so far as known it never forms as a result of hypogene hydrothermal processes, like dickite and nacrite, two of the other kaolin minerals. Like kaolinite, it forms through weathering and by the action of cool sulphate-bearing solutions on aluminous materials. ${ }^{29}$ Weathering is clearly the dominant source of kaolinite and probably of halloysite, but a considerable proportion of halloysite has been formed in areas where oxidizing sulphides have supplied sulphuric acid.

Residual halloysite.-The specimens of halloysite from Franklin and Hickory, N.C., are probably typical of halloysite in the residual white clays in the

\footnotetext{
${ }^{29}$ Ross, C. S., and Kerr, P. F., op. cit., pp. 172-174.
}

southeastern United States. Bayley ${ }^{30}$ has described the occurrence of the residual white clays in the vicinity of Franklin. He states: ${ }^{31}$

The kaolins of North Carolina have without doubt been formed directly or indirectly by the weathering of feldspathic rocks. Those in the mountain regions, where the surface waters have had almost direct access to the material of the pegmatite dikes, have been formed directly by weathering. The kaolins around Bessemer City, Bostick's Mills, and Statesville may have been formed somewhat differently. There the areas underlain by the clay are wide rather than long and narrow, as in the mountain district, and possibly the feldspathic rocks from which the kaolin has been derived were formerly covered by swampy tracts, so that the surface water percolating through them to the bedrock became charged with carbonic and organic acids, which not only accelerated the process of weathering but may have caused the removal of some iron that was in the parent rock.

Ries ${ }^{32}$ has given a review of the evidence for profound leaching and weathering of the white kaolins of the southeastern United States. As halloysite occurs mixed with kaolinite in such deposits, the two minerals are probably due to the same cause. It is suggested, however, that halloysite occurring under such conditions may represent a stage in the eventual crystallization of kaolinite. A similar origin observed in a white kaolinite clay from Brooklyn ${ }^{33}$ points to the formation of colloidal material in some localities prior to the crystallization of kaolinite.

At Rolla, Mo., profound leaching has produced diaspore surrounded by zones of flint clay. Some of the material from these deposits is called "burley clay" and is composed of knotlike masses of diaspore in flint clay that is made up dominantly of halloysite. The typical flint clays lying outside the zone of burley clay contain a larger proportion of halloysite but appear to be not entirely pure, and their mineralogy and paragenesis deserve detailed study.

Action of acid-bearing solutions.-Ries has pointed out that the so-called "indianaite" near Huron, in the southwest corner of Lawrence County, Ind., is not a distinct mineral species but a mixture of fine-grained minerals including halloysite. ${ }^{34}$ The studies here recorded show that the white porcelainlike material is commonly somewhat impure halloysite, but selected samples of very pure halloysite were obtained through the courtesy of Mr. George Whitlach, of Indiana University.

The origin of the white clay in Indiana has been studied by Ries, ${ }^{35}$ who concludes " that the white clay

\footnotetext{
${ }^{30}$ Bayley, W. S., High-grade clays of the eastern United States: U.S. Geol. Survey Bull. 708, p. 41, 1921.

31 Idem; p. 20.

${ }^{32}$ Ries, Heinrich, Origin of white residual kaolins: Am. Ceramic Soc. Trans., vol. 13, pp. 51-74, 1911.

${ }^{3}$ Kerr, P. F., Kaolinite from a Brooklyn subway tunnel: Am. Mineralogist, vol. 15, pp. 144-158, 1930.

${ }^{34}$ Ries, Heinrich, High-grade clays of the eastern United States: U.S. Geol. Survey Bull. 708, p. 156, 1921.

${ }^{35}$ Idem, pp. 159-162.
} 
was formed by the replacement of the quartz pebbles of Pottsville sandstone, at least where the clay occurs in that formation." Ries expresses the opinion that " the pyrite of the Chester shales would by contact with underground water be decomposed and yield sulyhuric acid, which would attack the alumina of the shales and form aluminum sulphate." A good path is present for circulating waters to follow, and it is thought by Ries that the aluminum sulphate solution replaces the quartz, forming halloysite and related minerals. This theory follows rather closely one preriously advanced by Logan, ${ }^{36}$ who proposed a biochemical origin for indianaite. He postulated the replacement of the sandstone by halloysite and presented a series of illustrations pointing out that origin. Logan, however, attributed the formation of halloysite to both the action of sulphuric acid solutions forming aluminum sulphate and to bacterial action, which precipitated the clay from the sulphate solutions when in contact with quartz. Bucher ${ }^{37}$ pointed out certain weaknesses in Logan's theory, and Ries in his studies of indianaite did not accept it. The three writers agree in assigning an important role to sulrhuric acid caused by the decomposition of iron sulphide and point to the action of meteoric waters as causing the solution, circulation, and deposition of the clay from the shale, but on the whole it seems quite unnecessary to postulate the action of bacteria in the formation of halloysite.

The association of alunite with halloysite as previously described is another evidence of the action of sulphate-bearing solutions in the formation of kaolinitic clays. Alunite was first detected in accounting for extra lines in an X-ray diffraction pattern of indianaite. Alunite is generally believed to form by precipitation from solutions carrying $\mathrm{H}_{2} \mathrm{SO}_{4},{ }^{38}$ and the presence of this mineral in association with halloysite would tend to support the theory of replacement by sulphate-bearing solutions in the Indiana occurrence.

The halloysite ("newtonite") locality in Newton County, Ark., is marked by prospect pits in a lead and zinc mining region. In this region oxidized zinc ores have resulted from the oxidation of sulphides, and it seems evident that the alunite and probably the halloysite have formed by the action on shales of waters containing sulphuric acid.

The halloysite from Liege, Belgium, is known to come from a region of old zinc mines, and its association with alunite makes it seem probable that sul-

\footnotetext{
${ }^{36}$ Logan, W. N., A biochemical theory of the origin of indianaite: Science, new ser., vol. 49, p. 197, 1919; Kaolin of Indiana: Indiana Dept. Conservation, Div. Geology, Pub. 6, pp. 35-76, 1919.

${ }^{37}$ Bucher, W. H., Logan's explanation of the origin of Indiana's "kaolin": Econ. Geology, vol. 16, no. 7, pp. 481-492, 1921.

${ }^{38}$ Cross, Whitman, Alunite deposits of Rosita Hills, Colю. : U.S. Geol. Survey Bull. 511, pp. $38-43,1912$. Ransome, F. L., The geology and ore deposits of Goldfield, Nev.: U.S. Geol. Survey Prof. Paper 66, pp. 189-195, 1909.
}

phuric acid solutions have played a part in producing the halloysite of that region. The description of halloysite furnished by Bucher (see p. 139) shows that oxidizing pyrite has been effective in producing that material in the Ohio region, and the same origin may probably be ascribed to the material from Hart County, Ky.

The deposits near Leakey, Tex., have not been studied in the field, but the association of halloysite with alunite and the presence of abundant disseminated flakes of hematite show that sulphur and iron bearing materials were present and oxidizing processes have been active. There is every reason to believe that the Leakey deposits were formed during the oxidation of pyrite and the action of the resulting acid-bearing solutions on the shales.

It therefore seems probable that the halloysite in at least six of the localities from which material considered in this paper was obtained was the result of the action of waters containing sulphuric acid.

\section{ALLOPHANE}

A clay mineral commonly associated with halloysite that may be considered in this paper is allophane. This material is of amorphous, commonly glassy character and variable composition. It forms incrustations; thin seams alternating with halloysite, as at Liege, Belgium; or rarely stalactitic masses. The purest material is clear and colorless, with a hyalitelike appearance, but may be blue, pale green, brown, or yellow.

\section{PREVIOUS STUDIES}

Allophane and related materials have been described under various names. It was observed by Riemann in 1809, at Gräfenthal, near Saalfield, in Thuringia, where it lines cavities in marl, and was named "allophane " by Stromeyer and Hausmann, in 1816. ${ }^{39}$ The name "riemannite" was applied to material from the same locality by Breithaupt ${ }^{40}$ the following year. Sack described "elhuyarit" ${ }^{41}$ from the brown coal of Friesdorf, near Bonn. Carolathine, a material similar to allophane but lower in water, was described by Sonnenschein, ${ }^{42}$ from Zabrze, near Gleiwitz, in upper Silesia.

In 1850 Dana $^{43}$ described samoit, which has since been listed under allophane. Optical examination of material from the same locality in the Roebling col-

\footnotetext{
${ }^{39}$ Stromeyer, F., and Hausmann, J. F. L., Göttingische Gelehrte Anzeigen, vol. 2, p. 125, 1816.

40 Breithaupt, A., in Hoffmann, C. A. S., Handbuch der Mineralogie, vol. 4 , p. 182,1817 .

${ }^{41}$ Sack, A. L., Schweigger's Jour. Chemie u. Phys., vol. 65, p. 116, 1832.

${ }^{42}$ Sonnenschein, F. L., Ueber das Carolathin: Deutsch, geol. Gesell. Zeitschr., vol. 5, pp 223-226, 1853.

${ }^{43}$ Dana, J. D., System of mineralogy, 3d ed., p. 288, 1850. Dana, E. S., idem, 6th ed., p. 693 .
} 
lection of the United States National Museum shows that it is not amorphous but crystalline and is probably montmorillonite rather than allophane.

Material described by Schrötter ${ }^{44}$ as opaline allophane from the vicinity of Freienstein, Styria, in 1837, was named "schrötterite" by Glocker ${ }^{45}$ in 1839.

These materials all agree in being amorphous and in containing essential silica and alumina with a large but variable proportion of water. Many specimens containing various proportions of bases have been reported, and plumballophane ${ }^{46}$ has been identified from Monte Vecchio, Sardinia. Allophane from Styria has a blue color due to the presence of chrysocolla. ${ }^{47}$. Small amounts of $\mathrm{SO}_{3}$ have been reported in the material from Styria and from Sand Mountain, Cherokee County, Ala. ${ }^{48}$ Some of the allophane studied in the preparation of this report was found to contain a notable proportion of $\mathrm{P}_{2} \mathrm{O}_{5}$.

The descriptions of allophane and related minerals given in the literature indicate the great variability of the materials. All are described as amorphous, but this term has been applied to very finely crystalline as well as truly amorphous material. An examination of samples labeled "allophane" in the collections of the United States National Museum shows that many of these are finely crystalline, being most commonly impure halloysite. It seems evident that only truly amorphous material should be termed "allophane" and that all crystalline or submicroscopically crystalline materials should be assigned to some other mineral. The X-ray methods of study have made it possible to distinguish amorphous from submicroscopically crystalline materials, as was not possible when these materials were first studied. The character of most of the previously described materials cannot be determined, as only a few are available for restudy, and old descriptions and analyses are for the most part useless. However, the published analyses serve to indicate the variability of the material that has been described as allophane and schrötterite. In 12 analyses of allophane given in the literature the $\mathrm{SiO}_{2}$ ranged from 21.39 to 39.13 percent, the $\mathrm{Al}_{2} \mathrm{O}_{3}$ from 23.52 to 41.66 percent, and the $\mathrm{H}_{2} \mathrm{O}$ from 33.06 to 43.96 percent.

4 Schrötter, Anton, Über den untheilbaren Opaline-Allophan, ein neue Mineral-Species: Zeitschr. Phys. u. Math., vol. 4, pp. 145-150, 1837.

${ }^{45}$ Glocler, E. F., Handbuch für Mineralogie, 2d ed., p. 536, 1839.

46 Bombicci, Luigi, Plumballofane di Sardegna: Soc. ital. sci. nat. Atti, vol. 11, pp. 114-118, 1868.

${ }^{47}$ Schrötter, Anton, Jour. prakt. Chemie, vol. 11, p. 380, 1837.

48 Mallett, J. W., On schrötterite from Cherokee County, Ala.: Am. Jour. Sci., vol. 26, p. 79,1858 .
That is, the silica-alumina ratio ranged from $0.74: 1$ to $1.98: 1$, about one-half being not far from 1:1. The ratio reported in schrötterite ranged from $2.15: 1$ to $2.73: 1$.

\section{CHEMICAL COMPOSITION}

Chemical analyses of five specimens of allophane from widely separated localities are given in the first table below, and analyses of related minerals in the next table.

Chemical analyses of allophane

\begin{tabular}{|c|c|c|c|c|c|}
\hline & $\begin{array}{l}\text { 1. Liege, } \\
\text { Belgiumm }\end{array}$ & $\begin{array}{l}\text { 2. More- } \\
\text { head, Ky. }\end{array}$ & 3. Laurium, & $\begin{array}{l}\text { 4. Dutchess } \\
\text { County, } \\
\text { N.Y. }\end{array}$ & $\begin{array}{l}\text { 5. Monte } \\
\text { Vecchio, } \\
\text { Sardinia }\end{array}$ \\
\hline $\begin{array}{l}\mathrm{SiO} \\
\mathrm{Al}_{2} \mathrm{O}_{3} \\
\mathrm{Fe}_{2} \mathrm{O}_{3}{ }^{\mathrm{a}} \\
\mathrm{MgO} \\
\mathrm{CaO} \\
\mathrm{K}_{2} \mathrm{O}+\mathrm{Na}_{2} \mathrm{O} \\
\mathrm{H}_{2} \mathrm{O}- \\
\mathrm{H}_{2} \mathrm{O}+ \\
\mathrm{TiO}_{2} \\
\mathrm{CuO} \\
\mathrm{ZnO} \\
\mathrm{CO}_{2} \\
\mathrm{P}_{2} \mathrm{O}_{5} \\
\mathrm{SO}_{3}\end{array}$ & $\begin{array}{r}33.96 \\
31.12 \\
\text { Trace } \\
2.26 \\
12.84 \\
20.28\end{array}$ & $\begin{array}{r}27.61 \\
32.29 \\
.23 \\
.10 \\
.02 \\
.10 \\
19.36 \\
18.05 \\
\text { None } \\
-72 \\
1.31 \\
.12\end{array}$ & $\begin{array}{r}28.60 \\
31.66 \\
.16 \\
.12 \\
.20 \\
.28 \\
19.26 \\
14.64 \\
\text { None } \\
.96 \\
2.62 \\
1.20 \\
\text { None } \\
.04\end{array}$ & $\begin{array}{r}25.19 \\
36.53 \\
.78 \\
.02 \\
.04 \\
.10 \\
21.20 \\
15.76 \\
\text { None } \\
1.04 \\
.02 \\
\text { None }\end{array}$ & $\begin{array}{r}32.30 \\
30.41 \\
.23 \\
.29 \\
.02 \\
.10 \\
16.38 \\
14.43 \\
\text { None } \\
1.60 \\
4.06 \\
.65 \\
.02 \\
.21\end{array}$ \\
\hline & 100. 46 & 99. 91 & 99.74 & 100. 68 & 100. 70 \\
\hline
\end{tabular}

a The iron is all assumed to be present as $\mathrm{Fe}_{2} \mathrm{O}_{3}$, as the ferrous iron in clay minerals is commonly within the limits of analytical error.

Analysis 1 by L. T. Richardson; $2-5$ by J. J. Fahey.

The materials whose analyses are given in the foregoing table are all essentially hydrous aluminum silicates with minor proportions of various bases. The water is high in all of them, varying from 30.81 to 38.00 . The ratio of aluminum to silica is as follows: Liege, 100:176; Morehead, 100:123; Laurium, 100:152; Dutchess County, 100:112; and Monte Vecchio, 100:180. All the samples of allophane contain bases, but they are negligible in the material from Morehead and are highest in the material from Monte Vecchio, where the ratio between total RO bases and silica is only about $1: 7$. The most abundant bases are copper and zinc in the specimens from Laurium and Monte Vecchio, where these minerals are associated with ore deposits.

Some of the specimens of allophane and schrötterite were found to have chemical compositions which indicated that they were intermediate between normal allophane and evansite. The chemical analyses of 
phosphate-bearing allophane and related evansite are given in the following table:

Chemical analyses of phosphate minerals.

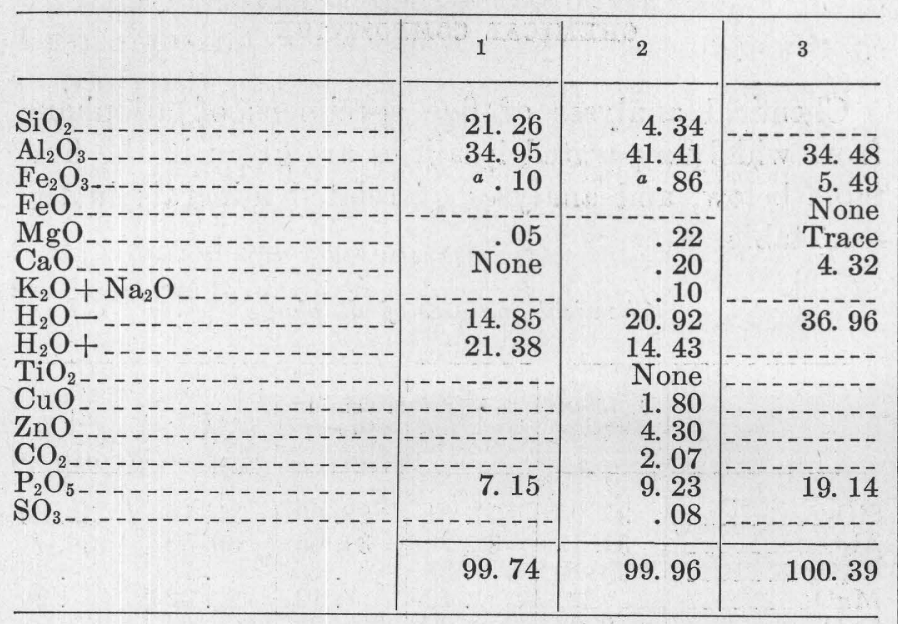

a The iron is all assumed to be present as $\mathrm{Fe}_{2} \mathrm{O}_{3}$.

Analyses 1 and 2 by J. J. Fahey; 3 by Waldemar T. Schaller (Evansite from two American localities: U.S. Geol. Survey Bull. 490, p. 94, 1911).

1. Allophane-evansite from Huron, Lawrence County, Ind., where it is associate 2. Allophane-

2. Allophane-evansite from Freienstein, Styria

The analysis of a specimen of beautiful water-clear allophane associated with halloysite (indianaite) from Huron, Ind., shows 7.15 percent of $\mathrm{P}_{2} \mathrm{O}_{5}$. A slightly blue "schrötterite" from Dollanger Mountain, Freienstein, Styria (Roebling collection of the National Museum), contains only 4.34 percent of silica but 9.23 percent of $\mathrm{P}_{2} \mathrm{O}_{5}$. Another specimen from Brandberg, Styria, showed abundant $\mathrm{P}_{2} \mathrm{O}_{5}$ by a qualitative chemical test. It has been previously recognized that schrötterite was probably not a definite mineral, for Helmhacker ${ }^{49}$ states that the schrötterite from the type locality (Freienstein, Styria) is a mixture of an earthy and a glassy clear material. The glassy material is halloysite and the earthy material variscite. Brendler ${ }^{50}$ reports that both the materials from Freienstein and Cherokee County, Ala., are mixtures of variscite and halloysite. "Schrötterite" from Saalfeld, Thuringia, has been analyzed by Zambonini ${ }^{5,1}$ but without testing for $\mathrm{P}_{2} \mathrm{O}_{5}$. This material has not been available for reexamination, but as $\mathrm{P}_{2} \mathrm{O}_{5}$ would not be recognized unless expressly looked for it may be present in the Thuringian material.

\footnotetext{
49 Helmhacker, R., Einige Mineralien aus der Gruppe der Thone: Min. pet. Mitt., Band 2, pp. 238-239, 1879.

${ }^{50}$ Brendler, Wolfgang, Mineralien-Sammlungen, Teil 2, p. 215, 1912.

${ }^{5}$ Zambonini, F., Melit, ein neues Aluminium-Eisen Hydrosilicat aus Thüringen, non Schrötterit beglietet: Zeitschr. Kryst. Min., vol. 32, p. 161, 1900; Über Millerit, Melit und Schrötterit: Idem, vol. 34, pp. 225-227, 1901.
}

A material to which the name viterbite has been applied, from Santa Rosa de Viterbo, Boyaca, Colombia, has the following chemical composition: ${ }^{52} \mathrm{SiO}_{2}$, $21.0 ; \mathrm{Al}_{2} \mathrm{O}_{3}, 40.0 ; \mathrm{Fe}_{2} \mathrm{O}_{3}, 2.3 ; \mathrm{P}_{2} \mathrm{O}_{5}, 6.0 ; \mathrm{H}_{2} \mathrm{O}, 30.7$. The index or refraction determined on type material is $n=1.476$. Thus the chemical and optical properties are similar to those of the allophane-evansite from Huron, Ind. A study of the foregoing analyses indicates that there may be all variations between typical phosphate-free allophane and evansite.

Optical studies, X-ray diffraction patterns, and dehydration curves all show that allophane and related materials have no definite atomic structure but are amorphous - that is, they are structureless mutual solutions of various oxides and water. Such materials can have no definite chemical composition, and wide variations in composition are to be expected. In discussing chrysocolla Foote and Bradley ${ }^{53}$ say:

The minerals which appear to present the greatest difficulty in the relations between actual composition and formula are those which commonly occur in the amorphous condition, but in these cases, as with well-crystallized minerals, definite formulae are commonly given in all reference works on the subject. An examination of the facts will show, however, that in many amorphous minerals the actual composition found may differ very widely indeed from the theoretical value required by the formula. * * * The mineral [chrysocolla] is not a chemical compound, and no formula should be assigned, but a solid solution of copper oxide, silica, and water as essential components, whose composition depends upon the conditions of formation. *** This tentative view of the composition of chrysocolla, if generally adopted, should logically be extended to a large number of minerals which commonly occur in the amorphous condition.

As allophane is essentially an amorphous solid solution of silica, alumina, and water, and evansite is an amorphous solid solution of phosphorus, alumina, and water, it is to be expected that the two types of material may occur together as a homogeneous mixture. It is also evident that other amorphous materials may enter into such a solution. Thus the allophanes from Greece and Styria contain copper, which no doubt represents chrysocolla that is in solution in the allophane.

The analyses reported in this paper and earlier studies by others have discredited all the known reported occurrences of schrötterite, including the type material, except only that from Thuringia, and even this may be phosphate-bearing. Even if an amorphous hydrous aluminum silicate with a higher pro-

52 Codazzi, R. L., Notas mineralógicas y petrográficas, p. 26, Bogotá, Biblioteca del Museo nacional, 1925.

${ }^{53}$ Foote, H. W., and Bradley, W. M., On the solid solution in minerals; IV, The composition of amorphous minerals as illustrated by chrysocolla: Am. Jour. Sci., 4th ser., vol. 33, pp. 180-184, 1913. 
portion of aluminum than normal allophane does exist, it is best grouped with allophane. It is therefore evident that schrötterite should be entirely discarded as a mineral name.

Materials of this type introduce a problem in mineral nomenclature. Crystalline minerals have definite compositions, or vary only within definite limits, and so differ fundamentally from the amorphous materials. For this reason such amorphous materials have been called "mineraloids" to distinguish them from true minerals, although they are commonly listed as minerals in nearly all mineralogies and no doubt will continue to be so classified. However, the assignment of distinct names to members of a group of amorphous materials differing only in the proportions of their essential constituents, as has been attempted for allophane and schrötterite, is not justified, but a single name should be applied to an entire group. On the other hand, it is evident that a different name should be applied where the essential constituents are different. Thus we would have allophane, evansite, and chrysocolla as distinct minerals or mineraloids. From their nature these minerals may show mixtures with one another, and when these mixtures reach roticeable proportions they may best be described by using the two names connected by a hyphen. Thus the mixtures considered in this paper may best be described as allophane-evansite and allophane-chrysocolla. It is to be distinctly understood, however, that these are not to be considered mineral species but merely mixtures of minerals.

\section{OPTICAL PROPERTIES}

The optical properties of a representative group of allophanes are given in the following table:

Optical properties of allophane and related phosphatic materials

\begin{tabular}{|c|c|c|c|c|}
\hline \multirow{2}{*}{ Locality } & \multirow{2}{*}{ Name } & \multirow{2}{*}{ Index of refraction } & \multicolumn{2}{|l|}{ Color } \\
\hline & & & Hand specimens & Thin sections \\
\hline $\begin{array}{l}\text { 1. Liege, Belgium } \\
\text { 2. Morehead, Ky } \\
\text { 3. Laurium, Greece } \\
\text { 4. Clove mine, Dutchess County, N.Y } \\
\text { 5. Monte Vecchio, Sardinia } \\
\text { 6. Bedford, Ind } \\
\text { 7. Huron, Lawrence County, Indiana } \\
\text { 8. Dollanger Mountain, Freienstein, Styria } \\
\text { 9. Brandberg, Styria } \\
\text { 10. Viterbo, Colombia } \\
\text { 11. Goldburg, Idaho }\end{array}$ & $\begin{array}{l}\text { Allophane. } \\
\text { Schrötterite } \\
\text { Eiterbite._- do do } \\
\text { Evansite... }\end{array}$ & 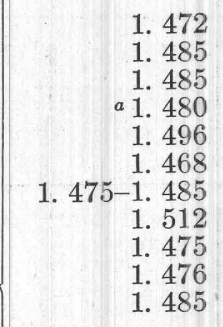 & $\begin{array}{l}\text { Colorless } \\
\text { Pale brown } \\
\text { Sky blue } \\
\text { Sulphur yellow } \\
\text { Light blue } \\
\text { Colorless } \\
\text { Pale blue } \\
\text { White } \\
\text { White to brown }\end{array}$ & $\begin{array}{c}\text { Colorless. } \\
\text { Do. } \\
\text { Do. } \\
\text { Do. } \\
\text { Very light blue. } \\
\text { Colorless. } \\
\text { Do. } \\
\text { Do. } \\
\text { Do. } \\
\text { Do. } \\
\text { Nearly colorless: }\end{array}$ \\
\hline
\end{tabular}

a Slightly variable.

No. 11 determined by F. E. Wright (Schaller, W. T., op. cit., p. 95); others by C. S. Ross.

This table shows that there is only a small variation in the indices of refraction, even where there is a large difference in the chemical composition; the greatest variation is from $n=1.468$ to $n=1.512$, and most of the specimens are not far from 1.485. It is therefore evident that these minerals cannot be distinguished either by the optical or the X-ray properties, and chemical analyses are necessary. X-ray diffraction patterns are characterized by absence of all but traces of lines. One diffused band and traces of others are all that appear. Such traces as can be ubserved, however, are the same in different patterns.

\section{DEHYDRATION}

Two typical allophanes have been subjected to dehydration tests, and the results are given in the following table and the curves in figure 8.
Dehydration data of allophane

\begin{tabular}{|c|c|c|c|}
\hline \multicolumn{2}{|c|}{ Liege, Belgium } & \multicolumn{2}{c|}{ Morehead, Ky. } \\
\cline { 1 - 3 } Temperature & Loss of water & Temperature & Loss of water \\
\hline & & & \\
\hline$\left({ }^{\circ}\right.$ C.) & Percent & ${ }^{\circ}$ C. $)$ & Percent \\
26 & 0 & 26 & 0 \\
120 & 15.00 & 40 & 4.99 \\
160 & 18.60 & 100 & 12.98 \\
185 & 19.67 & 160 & 15.88 \\
201 & 20.18 & 240 & 18.47 \\
225 & 20.67 & 300 & 19.78 \\
250 & 21.79 & 410 & 22.06 \\
285 & 23.52 & 562 & 25.58 \\
330 & 25.04 & 615 & 25.71 \\
360 & 25.95 & 795 & 27.34 \\
450 & 28.93 & & \\
502 & 29.71 & & \\
570 & 30.38 & & \\
630 & 30.92 & & \\
710 & 31.27 & & \\
850 & 31.67 & & \\
& & & \\
\hline
\end{tabular}


The dehydration data given in the preceding table $\mid$ in the high-temperature water of combination in and the dehydration curves plotted therefrom show a gradually decreasing loss of water, with no break or halloysite.

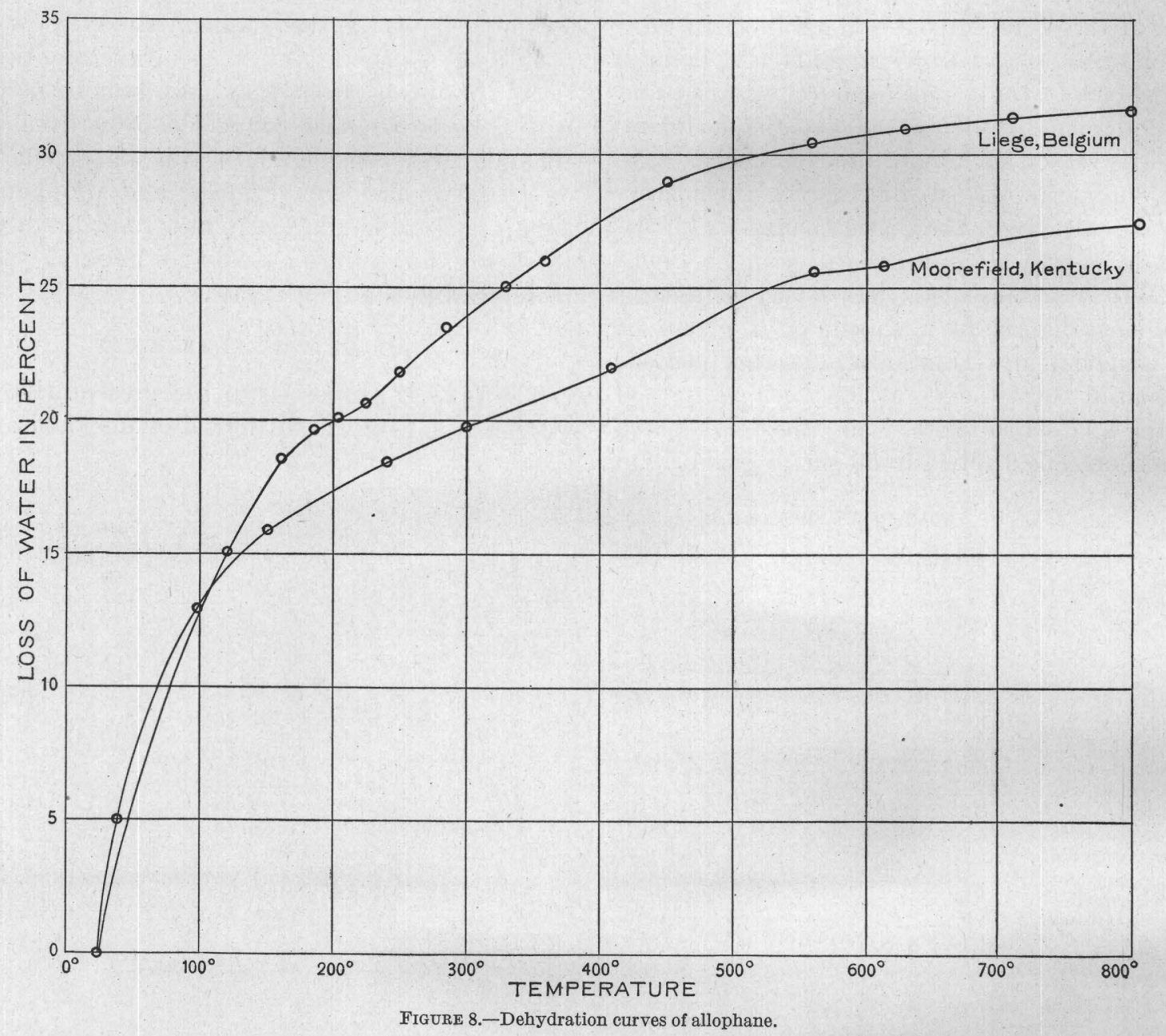

prominent flexures. This shows that in allophane there is no difference in the manner in which the water is combined at high and low temperatures. The curves are characteristic of a material in which the water is held in solution and not in chemical combination, as
This confirms the chemical and X-ray data, which show that allophane has no definite atomic structure or chemical composition and is a mutual solution of silica, alumina, water, and minor bases and accessory acid radicles. 